\title{
ANALISIS SISTEM PEMPROSESAN TRANSAKSI PADA SIKLUS REVENUE PT SIG
}

\author{
Arthaingan H. Mutiha ${ }^{1}$ \\ ${ }^{1}$ Laboratorium Akuntansi, Program Vokasi UI, ah_mutiha@yahoo.co.id
}

Diterima : 17 Februari 2014

Layak Terbit : 1 Juli 2014

\begin{abstract}
Abstrak
Sistem informasi akuntansi yang baik adalah sistem informasi yang dapat menghasilkan informasi yang akurat, tepat waktu dan dapat diandalkan untuk menjadi dasar pengambilan keputusan manajemen. Selain itu penggunaan database untuk menyimpan transaksi keuangan dan operasional harus terintegrasi. Database yang terintegrasi memastikan bahwa tidak akan terjadi pengulangan data dan memastikan data yang ada adalah data yang paling up-date. Database yang berdiri sendiri diantara tiap bagian (tidak terintegrasi) akan mengakibatkan penghabisan waktu, mahal dan bisa terjadi ketidakkonsistenan. Hal ini jelas merupakan kekurangan yang dapat menghambat perusahaan untuk bersaing. PT SIG adalah perusahaan yang bergerak dalam jasa freight forwarding. Salah satu fungsi utama jasa Freight Forwarding adalah memberikan jasa pengurusan transportasi pengiriman barang dan pengurusan dokumen yang terkait dengan pengiriman tersebut. Dokumen yang berkaitan dalam industri ini sangat kompleks. Suatu barang baru dapat dikirimkan atau diterima di tujuan bila seluruh dokumen telah diisi dengan lengkap, benar dan tepat waktu. Sayangnya, perusahaan belum dapat mengatur fungsi pengurusan dokumen dengan efektif dan efisien. Pemodelan proses mencakup proses aliran data yang dimodelkan dengan Diagram Arus Data. Analisa Sistem Informasi PT SIG ini mampu memberi masukan untuk mengatasi kebutuhan masalah perusahaan selain itu diharapkan penerapan sistem ini dapat melayani pelanggan dengan lebih baik lagi.
\end{abstract}

Kata kunci : analisa sistem informasi, pemodelan proses, diagram arus data

\begin{abstract}
Good accounting information system is information system that can generate accurate, on time and reliable information for management decision making. The use of database to keep the financial transaction and operasional transaction data must be integrated. Integrated database will avoid redundant data and keep the currency of data. Single database in each division will be time consuming, expensive and will cause inconsistency of data. This will be the disadvantage for the company to compete. PT SIG is the company operating in freight forwarding industry. One of the main responsibility is to manage the delivery of package from one place to another place all over the world and to manage all documents related to the shipping. The management of documents in this industry is very complex, therefore the need to handle the documents in the efficient, complete, fast and zero errror is the prime need of the management. The documents distributed in this industry are complex. The shipment of the package can be performed if the whole documents are complete. Unfortunatelly, the company can not manage its documents efficiently and effectively. The reliable accounting information system is the system that can generate accurate, on time and reliable information for management decision making and to serve customer in a better way.
\end{abstract}

Keyword : analysis information system, proces modelling, data flow diagram 


\section{PENDAHULUAN}

\section{Latar Belakang}

Dalam menjalankan operasi atau kegiatannya sehari-hari, organisasi sangat mengandalkan dirinya pada suatu sistem informasi. Sistem informasi yang andal harus dapat memastikan bahwa pengguna sistem informasi dapat memperoleh informasi yang berguna untuk pengambilan keputusan secara cepat dari segi waktu dan relatif murah dari segi biaya bila dibandingkan dengan pesaingnya. Hal ini akan memberikan nilai tambah bagi perusahaan di mata para pelanggannya.

Informasi adalah merupakan sumber daya yang dimiliki perusahaan dan memiliki peran yang sama pentingnya seperti sumber daya uang, pabrik dan mesin. Organisasi yang sanggup mengolah informasi dengan baik akan sanggup berkompetisi dan bertahan hidup di dalam industrinya.

Informasi akan lebih efisien bila diolah menggunakan tekhnologi berbasis komputer.

Sistem informasi berbasis komputer merupakan kelompok perangkat keras dan perangkat lunak yang dirancang untuk mengubah data menjadi informasi yang dapat digunakan oleh pengambil keputusan secara tepat waktu dan andal.

PT SIG adalah perusahaan yang bergerak dalam industri freight forwarding (jasa pengurusan transportasi dan dokumen yang terkait dengan pengurusan transportasi tersebut). Secara umum, Freigt Forwarding adalah kegiatan usaha yang ditujukan mengurus semua kegiatan yang diperlukan bagi terlaksananya pengiriman dan penerimaan barang melalui trasnportasi darat, laut dan udara yang mencakup kegiatan penerimaan, penyimpanan, sortasi, pengepakan, pengukuran, penimbangan, pengurusan penyelesaian dokumen dan halhal yang terkait dengan pengiriman barang sampai dengan diterimanya barang oleh yang berhak menerimanya. Perusahaan Jasa Freight Forwarding bertanggung jawab mulai dari barang diterima di tempat pengiriman sampai barang diserahkan di tempat penerima dan mengatur pengangkutan menggunakan trasnportasi laut, darat dan udara. Salah satu fungsi utama dari jasa freight forwarding adalah fungsi pengurusan dokumen sehingga barang dapat dikirim atau diterima pemilik barang. Dokumen yang berkaitan dalam kepengurusan barang dalam industri ini sangat kompleks. Suatu barang baru dapat diterima atau dikirimkan ke tempat tujuan (ekport dan import) bila seluruh dokumen telah diisi dengan lengkap, benar dan tepat waktu. Pengiriman barang bisa dan harus ditunda bila dokumen yag terkait dengan pengiriman kurang lengkap. Sayangnya, perusahaan belum dapat mengatur fungsi kepengurusan dokumen dengan efektif dan efisien. Dokumen masih ditulis secara manual dan didistribusikan ke bagian lainnya secara manual pula. Pembuatan dokumen yang dilakukan secara manual berpotensi terjadinya kesalahan yang relatif tinggi. Dapat dibayangkan, dokumen yang salah dan telah beredar ke entitas di luar perusahaan kemudian harus kembali lagi untuk dikoreksi. Disini akan terjadi pemborosan waktu dan tenaga. Pemborosan waktu mengakibatkan si penerima barang tidak bisa mengambil barangnya di dermaga, hal ini pada akhirnya akan mengakibatkan denda yang tidak diperlukan karena tertumpuknya barang di pelabuhan atau gudang.

Selain itu, masing-masing bagian seperti bagian penjualan, bagian operasi dan bagian keuangan dan akuntansi masih memiliki database yang independen (tidak terintegrasi). Sehingga bila unsur data yang sama namun dimasukkan dalam aplikasi yang berbeda akan mengakibatkan penghabisan waktu, mahal dan dapat menimbulkan ketidakkonsistenan data. Jelas ini merupakan kekurangan yang dapat menghambat perusahaan untuk bersaing.

Adanya database yang terintegrasi dan adanya sistem informasi pengolahan dokumen berbasis komputer dipastikan akan menjadikan proses pengolahan dokumen menjadi relatif lebih cepat dan akurat. Ini akan menjadi nilai tambah bagi perusahaan dalam meningkatkan efisiensi proses operasinya.

Dalam industri Freight Forwarding, fungsi kepengurusan dokumen yang benar, lengkap dan cepat adalah modal utama perusahaan untuk bertahan dalam industrinya. Untuk itu, PT MPC dituntut untuk memperbaiki sistem informasi pengolahan dokumennya untuk dapat mendukung pemrosesan transaksi perusahaan. 


\section{Metode Penelitian}

Berdasarkan permasalahan yang ada, maka masalah dalam penelitian ini adalah melakukan analisis sistem informasi pada PT SIG khususnya divisi keuangan dan administrasi guna mendukung perusahaan dalam meningkatkan pelayanannya. Penelitian ini dibatasi pada analisa transaksi pada divisi keuangan dan divisi administrasi operasi. Tahap analisis sistem adalah tahap yang harus dilakukan sebelum melangkah ke tahap perancangan sistem sehingga dapat dikatakan bahwa tahap ini memiliki fokus utama pada masalah kebutuhan informasi perusahaan, terlepas dari masalah pemilihan tekhnologi yang akan digunakan dalam mengimplementasikan sistem. Sementara itu, tahap perancangan sistem tidak termasuk dalam bahasan penelitian ini.

Keterkaitan divisi keuangan dan divisi administrasi sangat erat, sehingga kordinasi keduanya menjadi modal utama dalam proses operasi perusahaan, terutama dalam kaitannya dengan proses pengajuan uang muka pelaksanaan suatu kegiatan hingga penagihan kepada pelanggan. Oleh karena itu, analisa sistem informasi pada penelitian ini dikhususkan pada divisi administrasi operasi dan divisi keuangan dari mulai proses pengajuan uang muka hingga penagihan kepada pelanggan.

a).Memberikan gambaran yang jelas mengenai prosedur transaksi yang terjadi di perusahaan khususnya divisi administrasi operasi dan keuangan pada perusahaan PT SIG khususnya siklus revenue perusahaan dimulai dari proses penerimaan pesanan hingga kepada pelanggan.

b).Melakukan analisa dan merancang sistem informasi akuntansi perusahaan terkait prosedur transaksi pada divisi administrasi dan keuangan dari mulai pengajuan uang muka hingga penagihan kepada pelanggan, melalui pemodelan proses Data Flow

Diagram (DFD). Penelitian ini dilakukan melalui studi kasus mengenai kegiatan operasional PT MPC dengan menggunakan dua pendekatan yaitu studi lapangan dan studi pustaka. Studi lapangan dilakukan melalui wawancara dengan staf PT MPC sementara studi pustaka dilakukan dengan menggunakan buku teks dan buku penunjang lainnya.
Kualitas dari suatu sistem informasi tergantung dari tiga hal yakni informasi yang dihasilkan dari sistem tersebut harus akurat, tepat waktu dan relevan. Akurat berarti informasi harus bebas dari kesalahankesalahan dan tidak bias atau menyesatkan. Akurat juga berarti informasi harus jelas dan mencerminkan tujuannya. Tepat pada waktunya, berarti informasi yang datang pada penerima tidak boleh terlambat. Bila pengambilan keputusan terlambat, maka dapat berakibat fatal bagi organisasi.

Sistem adalah suatu kumpulan dari dua atau lebih komponen yang saling berhubungan dan berinteraksi untuk mencapai suatu tujuan. Sistem terdiri dari suatu sub sistem yang kecil yang masing-masing melakukan suatu fungsi khusus yang penting untuk mendukung sistem yang lebih besar dimana sub sistem tersebut merupakan bagiannya.

Maka definisi dari suatu sistem informasi adalah susunan dari manusia, data, proses, tampilan informasi dan tekhnologi yang berinteraksi untuk mendukung dan meningkatkan operasional sehari-hari dalam bisnis, seperti mendukung pemecahan masalah.Dalam proses pengembangan suatu sistem, ada dua tahap yang perlu untuk dijalani yakni tahap analisis sistem dan kemudian dilanjutkan dengan perancangan sistem. Analisis sistem adalah suatu tekhnik pemecahan masalah dengan memecah suatu sistem mejadi beberapa komponen dengan maksud untuk mempelajari seberapa baik komponen tersebut berfungsi dan saling berinteraksi untuk mencapai tujuannya

\section{HASIL DAN PEMBAHASAN}

Analisa terstruktur menggambarkan model prosesnya dalam Diagram Arus Data atau Data Flow Diagram yang selanjutnya disingkat menjadi DFD. DFD mengilustrasikan proses yang ada atau yang ditawarkan bersamaan dengan masukan, keluaran dan files yang terkait.

Pemodelan proses adalah tekhnik yang digunakan untuk mengorganisasikan dan medokumentasikan struktur dan arus data melalui proses sistem atau logika, kebijakan dan prosedur yang akan diimplementasikan oleh proses sistem. Dalam menggambarkan sistem perlu dilakukan pembentukan simbol, berikut adalah simbol-simbol yang sering digunakan dalam arus data : 
Nama Proses
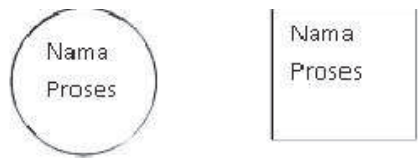

Gambar 1. Simbol Proses kegiatan atau kerja

Setiap proses harus diberi penjelasan yang lengkap meliputi :

a) Identifikasi Proses

Identifikasi ini umumnya berupa angka yang menunjukkan nomor acuan dari proses dan ditulis pada bagian atas simbol proses.

b) Nama Proses

Nama Proses menunjukkan apa yang dikerjakan oleh proses tersebut. Nama proses harus jelas dan lengkap menggambarkan kegiatan proses. Nama proses biasaya berbentuk suatu kalimat yang diawali dengan kata kerja dan letaknya berada dibawah identifikasi proses.

c) Arus Data

Arus data pada diagram arus data diberi simbol panah. Arus data ini mengalir diantara proses, penyimpanan data dan kesatuan luar (environment). Arus data ini menunjukkan arus data atau aliran data yang dapat berupa masukan untuk suatu sistem atau hasil dari proses sistem. Arus data sebaiknya diberi nama yang jelas dan mempunya arti. Nama dari arus data dituliskan di atas garis panahnya. Simbol untuk arus data dapat dilihat pada gambar dibawah ini :

\section{Gambar 2. Simbol Arus Data}

\section{d) Agen Eksternal}

Setiap sistem pasti memiliki batas sistem yang memisahkan suatu sistem dengan lingkungan luarnya. Sistem akan menerima input dan menghasilkan output bagi lingkungan luarnya. Entitas eksternal merupakan kesatuan di lingkungan luar sistem yang dapat berupa orang, organisasi atau sistem lain yang berada di lingkungan luarnya yang akan memberi input serta menerima output dari sistem. Suatu entitas eksternal dapat disimbolkan dengan notasi kotak dan dapat dilihat pada gambar berikut ini :

Nama Agen Eksternal

Gambar 3. Simbol Nama Agen eksternal e) Penyimpanan data

Penyimpanan data adalah suatu inventory atas data, nama lainnnya adalah file dan basis data. Jika arus data adalah pergerakan data, maka penyimpanan data adalah tempat dimana data akan berhenti. Penyimpanan data haruslah menggambarkan tentang sesuatu dimana datanya ingin disimpan dalam suatu proses bisnis. Nama dari suatu data store menunjukkan nama dari file.

Penyimpanan data store dapat disimbolkan sebagai berikut :

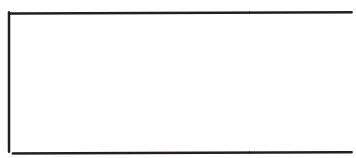

Gambar 4. Simbol penyimpanan data

Proses logis adalah pekerjaan yang harus dilakukan tanpa memperhatikan bagaimana sistem tersebut diimplementasikan. Model proses logis menghilangkan semua proses yang hanya memindahkan atau menggeser data, sehingga tidak terjadi perubahan terhadap data tersebut. Dalam analisis sistem lebih difokuskan untuk membangun model proses logis sebagai bagian dari persyaratan bisnis. Proses logis ini mendeskripsikan syarat pemrosesan bisnis dari suatu sistem namun bukan solusi tekhnisnya.

Tahap-tahap dalam membangun pemodelan proses adalah sebagai berikut :

1. Membangun diagram arus data konteks (contex data flow diagram).

Diagram Arus Data Konteks mendefinisikan ruang lingkup dan batasan dari suatu sistem. Ruang lingkup sistem adalah aspek-aspek bisnis apa saja yang akan didukung oleh suatu sistem atau aplikasi. Selain itu, ruang lingkup sistem juga mendefinisikan bagaimana sistem tersebut akan memodelkan hubungan/interaksi yang terjadi dengan sistem lainnya dan bisnis secara keseluruhan.

2. Membuat diagram dekomposisi yang memperlihatkan pemecahan sistem ke dalam fungsi-fungsinya

3. Menentukan peristiwa-peristiwa (events) yang terjadi dalam suatu sistem yang perlu direspon dan juga menentukan respon apa yang sesuai dengan peristiwa 
tersebut. Events dapat digolongkan menjadi tiga macam, yakni external events, temporal events (pemicu proses yang berdasarkan waktu) dan state events (pemicu proses yang berdasarkan suatu perubahan kondisi).

4. Membuat diagram dekomposisi peristiwa. Hal ini dapat dilakukan jika peristiwa yang terjadi sederhana karena diagram dekomposisi pertistiwa bertujuan untuk memudahkan pemahaman atas suatu peristiwa yang rumit dan memecahnya ke dalam tingkat yang lebih sederhana.

5. Membuat diagram peristiwa

Diagram peristiwa adalah suatu diagram konteks untuk suatu peristiwa tunggal yang memperlihatkan interaksi masukan, keluaran, dan penyimpanan data suatu peristiwa. Hal ini dapat dilakukan dengan menggunakan diagram dekomposisi sebagai acuan.

1. Gambaran proses transaksi perusahaan Kegiatan operasional perusahaan terbagi atas tiga kegiatan utama yaitu kegiatan domestik, ekspor dan import. Kegiatan ekspor dan impor memiliki prosedur kerja yang berbeda sedangkan untuk domestik hampir menyerupai kegiatan ekspor dan impor saja hanya lebih sederhana.

Prosedur Operasi Impor Freight

1. Prosedur penerimaan booking dari importir

a. Menerima RFQ (Request for Quotation) Kegiatan impor untuk semua proses diawali dengan masuknya pesanan dari importir. RFQ dapat diterima perusahaan memalui fax, telepon. RFQ ini memuat nama perusahaan importir, cakupan pekerjaan yang diinginkan, jumlah, ukuran dan jenis barang, tujuan pengiriman, waktu pekerjaan dan penyerahan.

b. Membuat PQ (Price Quotation)

Berdasarkan RFQ, bagian operation yang dapat berfungsi sebagai sales dan marketing perusashaan dapat membuat $\mathrm{PQ}$ (Price Quotation) kepada importir. PQ ini memuat penawaran biaya atas cakupan pekerjaan yang dikehendaki. $\mathrm{PQ}$ ini kemudian dikirimkan dan difax ke importir untuk dipertimbangkan oleh importir apakah harga yang diberikan disetujui.

c. Mengisi CFOR (Cost Freight Order Report) Jika order jadi disetujui maka pekerjaan pertama yang dilakukan adalah mengisi CFOR. CFOR merupaka form yang menguraikan cakupan pekerjaan dan biaya yang dikeluarkan oleh perusahaan atas pekerjaan tersebut dan fee yang akan diterima oleh perusahaan. Dengan begitu dapat diketahui rugi/laba atas pekerjaan yang ditanganinya. Jika pekerjaan sudah selesai dan barang sudah dikirimkan maka CFOR ini dilengkapi kemudian diserahkan kepada bagian keuangan untuk dijadikan acuan untuk membuat tagihan kepada importir.

2. Prosedur pengajuan budget dana operasi Untuk melakukan kegiatan operasional mulai dari menukar Master $\mathrm{B} / \mathrm{L}$ dengan $\mathrm{D} / \mathrm{O}$ Container dan lainnya tentu dibutuhkan biaya. Untuk itu bagian operasi mengajukan budjet dana operasi kepada bagian keuangan dengan mengisi Bon Sementara (BS). Pada BS ini dituliskan No CFOR untuk importir yang bersangkutan, nama importir dan jumlah biaya yang dibutuhkan. Semua form ini ditandatangani oleh penerima tanggung jawab dari bagian operasi (manajer operasi), penerima uang (staf operasi), dan disetujui dibayar oleh bagian keuangan. Setelah disetujui, maka kasir akan menyerahkan sejumlah uang sesuai dengan jumlah yang tertera di BS.

3. Prosedur Pertanggungjawaban biaya operasi

Untuk membuat laporan pertanggung jawaban keuangan, bagian operation harus menyerahkan form Bayar Kas/Bank yang telah diisi sesuai dengan biaya yang dikeluarkan dengan melampirkan dokumen pendukung berupa bukti/kwitansi pembayaran atas biayabiaya tersebut, berikut CFOR. Dengan menyerahkan laporan tersebut maka BS sebagai bukti hutang bagian operasi kepada keuangan dapat ditarik.

4. Prosedur Penagihan Pembayaran

Berdasarkan laporan yang diterima dari bagian operation, bagian keuangan akan membuat dan mengirimkan tagihan kepada importir untuk menagih semua biaya yang dikeluarkan sehubungan dengan jasa yang digunakan.

Prosedur Operasi Ekspor Freight

1. Prosedur penerimaan booking dari eksportir

a. Menerima RFQ (Request for Quotation) Kegiatan ekpor untuk semua proses diawali dengan masuknya pesanan dari eksportir. RFQ dapat diterima perusahaan melalui fax, telepon. RFQ ini memuat nama perusahaan eksportir, cakupan pekerjaan yang diinginkan, jumlah, ukuran dan jenis barang, tujuan pengiriman, waktu pekerjaan dan penyerahan. 
Tabel 1.1

Matriks Pernyataan Masalah Sistem Informasi Operasi PT SIG

\begin{tabular}{|c|c|c|c|c|c|}
\hline No & Masalah & Urgensitas & Visibilitas & Prioritas & Solusi \\
\hline 1. & $\begin{array}{l}\text { Perolehan Data yang } \\
\text { dibutuhkan manajemen } \\
\text { untuk pengambilan } \\
\text { keputusan relatif lama }\end{array}$ & Penting & Tinggi & 1 & $\begin{array}{l}\text { Pembangunan } \\
\text { sistem } \\
\text { informasi PT } \\
\text { SIG }\end{array}$ \\
\hline 2. & $\begin{array}{l}\text { Waktu pelayanan } \\
\text { konsumen untuk } \\
\text { memproses dokumen, } \\
\text { seperti proses dokumen } \\
\text { Price Quotation dan } \\
\text { dokumen ekpor impor } \\
\text { relatif lama }\end{array}$ & Penting & Tinggi & 1 & \\
\hline 3. & $\begin{array}{lr}\text { Staf } & \text { marketing } \\
\text { memberikan } & \text { price } \\
\text { quotation } & \text { yang } \\
\text { berbeda-beda. Hal ini } \\
\text { jelas } \\
\begin{array}{l}\text { perusahaan di mata } \\
\text { pelanggan }\end{array}\end{array}$ & Penting & Tinggi & 1 & \\
\hline
\end{tabular}

Sumber : Data diolah

b. Membuat PQ (Price Quotation)

Berdasarkan RFQ, bagian operation yang dapat berfungsi sebagai sales dan marketing perusahaan dapat membuat PQ (Price Quotation) kepada eksportir. PQ ini memuat penawaran biaya atas cakupan pekerjaan yang dikehendaki. PQ ini kemudian dikirimkan dan difax ke eksportir untuk dipertimbangkan oleh eksportir apakah harga yang diberikan disetujui.

c. Mengisi CFOR (Cost Freight Order Report)

Jika order disetujui maka pekerjaan pertama yang dilakukan adalah mengisi CFOR.

CFOR merupaka form yang menguraikan cakupan pekerjaan dan biaya yang dikeluarkan oleh perusahaan atas pekerjaan tersebut dan fee yang akan diterima oleh perusahaan.
Dengan begitu dapat diketahui profit atas pekerjaan yang ditanganinya. Jika pekerjaan sudah selesai dan barang sudah dikirimkan maka CFOR ini dilengkapi kemudian diserahkan kepada bagian keuangan untuk dijadikan acuan untuk membuat tagihan kepada eksportir.

d. Prosedur pengajuan budget dana operasi Untuk melakukan kegiatan operasional mulai dari menukar Master B/L dengan $\mathrm{D} / \mathrm{O}$ Container dan lainnya tentu dibutuhkan biaya. Untuk itu bagian operasi mengajukan budjet dana operasi kepada bagian keuangan dengan mengisi Bon Sementara (BS). Pada BS ini dituliskan No CFOR untuk eksportir yang bersangkutan, nama eksportir dan jumlah biaya yang dibutuhkan.

Semua form ini ditandatangani oleh penerima tanggung jawab dari bagian operasi (manajer operasi), penerima uang 
(staf operasi), dan disetujui dibayar oleh bagian keuangan. Setelah disetujui, maka kasir akan menyerahkan sejumlah uang sesuai dengan jumlah yang tertera di BS.

e. Prosedur Pertanggungjawaban biaya operasi

Untuk membuat laporan pertanggungjawaban keuangan, bagian operasi harus menyerahkan form Bayar Kas/Bank yang telah diisi sesuai dengan biaya yang dikeluarkan dengan melampirkan dokumen pendukung berupa bukti/kwitansi pembayaran atas biayabiaya tersebut, berikut CFOR. Dengan menyerahkan laporan tersebut maka BS sebagai bukti hutang bagian operasi kepada bagian keuangan dapat ditarik dan dianggap selesai.
Pernyataan masalah yang ada akan dijabarkan dalam Matriks Pernyataan Masalah berikut ini. Matriks ini akan memperlihatkan penilaian penulis atas tingkat urgensitas, visibilitas dan prioritas dalam menyelesaikan masalah yang teridentifikasi.

Permasalahan diatas dapat menghambat perusahaan untuk berkompetisi, apalagi dengan adanya tuntutan dari pelanggan agar perusahaan dapat memiliki sertifikasi ISO 9002. Oleh karena itu, untuk mengatasi masalah tersebut diusulkan untuk membangun suatu sistem informasi pada PT SIG

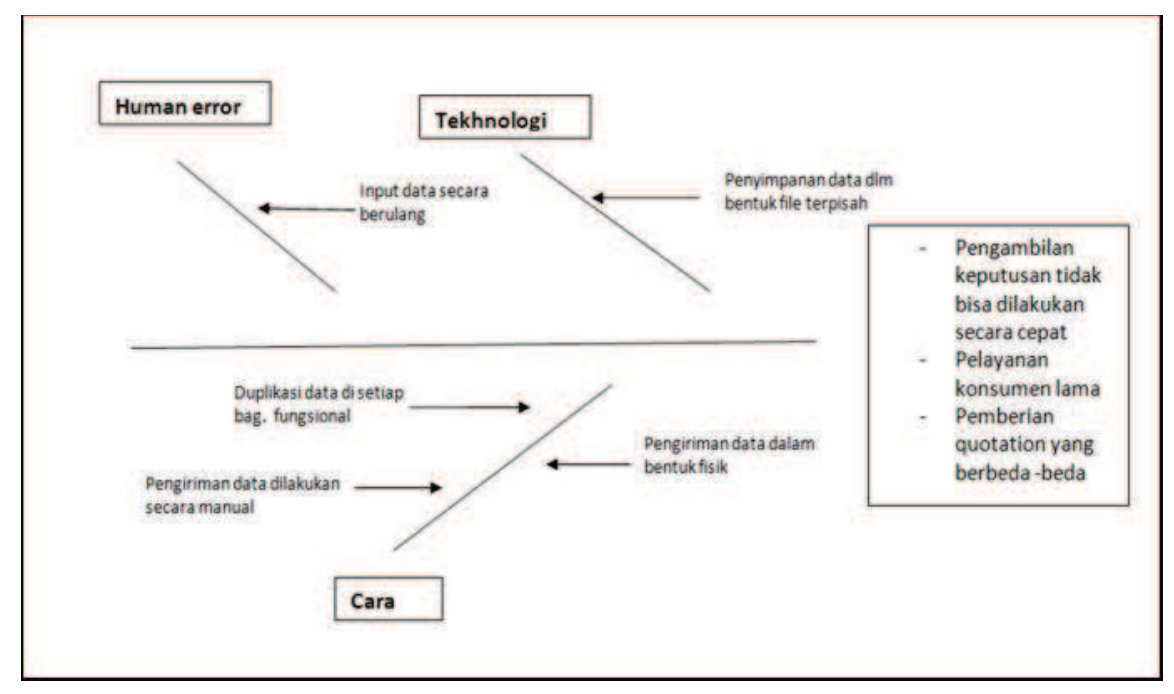

Gambar 5

Diagram Fish Bone

Sumber : Analisis cause and effect.Data proses PT, SIG

5. Prosedur Penagihan Pembayaran

Berdasarkan laporan yang diterima dari bagian operasi, bagian keuangan akan membuat dan mengirimkan tagihan kepada eksportir untuk menagih semua biaya yang dikeluarkan sehubungan dengan jasa yang digunakan.

2. Analisa dan perancangan Data Flow Diagram

2.1 Investigasi Awal

Adanya usulan untuk mengembangkan sistem informasi operasi pada perusahaan adalah karena adanya masalah yang terjadi dari mulai proses penerimaan pesanan dari pelanggan (proses booking) hingga proses penagihan pembayaran.
Tahap analisis masalah adalah tahapan mempelajari dan menganalisa masalah yang telah diidentifikasi dalam tahap awal secara lebih detail. Salah satu tujuan dari tahapan ini adalah antara lain menemukan letak sumber masalah dan menentukan tujuan pengembangan sistem. Masalah yang telah diidentifikasi dalam matriks pernyataan masalah, dianalisis untuk menentukan tujuan dan batasan sistem.

Pada pembahasan ini, pendekatan yang digunakan dalam melakukan analisis masalah adalah analisis sebab akibat (cause \& effect). 
Analisis cause and effect digambarkan melalui diagram Fishbone gambar 5.
Melalui diagram aliran konteks terlihat bahwa sistem operasi PT MPC mempunyai 3 (tiga) external agents yaitu : Pelanggan, Shipping Line dan Operation.

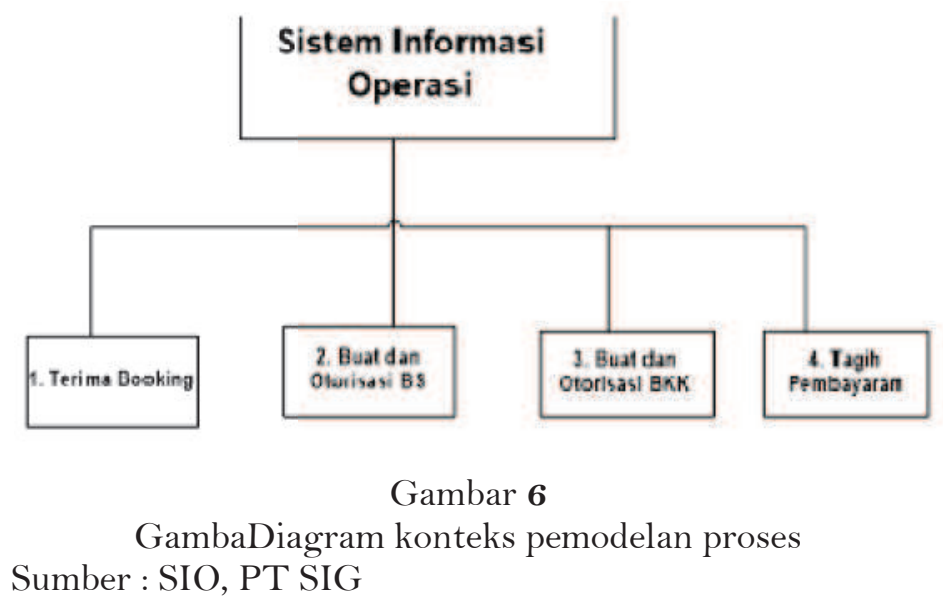

1. Analisis kebutuhan

Pendekatan yang digunakan untuk mendokumentasikan kebutuhan-kebutuhan fungsional pada sistem informasi PT SIG adalah pemodelan sistem berupa model logika yang meliputi pemodelan data dan pemodelan proses. Pemodelan data dilakukan dengan menggambarkan diagram hubungan entitas sedangkan pemodelan proses dilakukan dengan menggambarkan diagram aliran data atau data flow diagram. Dalam penelitian ini pemodelan yang dilakukan adalah sebatas pemodelan proses.

a. Pemodelan proses

Tahap-tahap yang dilakukan dalam menbangun pemodelan proses adalah sebagai berikut :

1. Membangun diagram aliran data koleksi.

Diagram aliran data konteks dirancang untuk mendefinisikan batasan dan ruang lingkup untuk sistem, untuk menggambarkan bagaimana sistem harus berinteraksi dengan sistem lain dan serta menggambarkan bisinis secara keseluruhan.
2. Membangun Diagram Dekomposisi Fungsional

Setelah menggambar diagram aliran data konteks, langkah selanjutnya dalam membangun pemodelan proses logikal adalah menggambar diagram dekomposisi fungsional untuk membagi sistem kedalam subsistem-subsistem atau fungsifungsi secara logis, sehingga sistem lebih mudah untuk dimengerti.

Diagram dekomposisi fungsional Sistem Informasi Operasi PT SIG adalah sebagai berikut ini : 


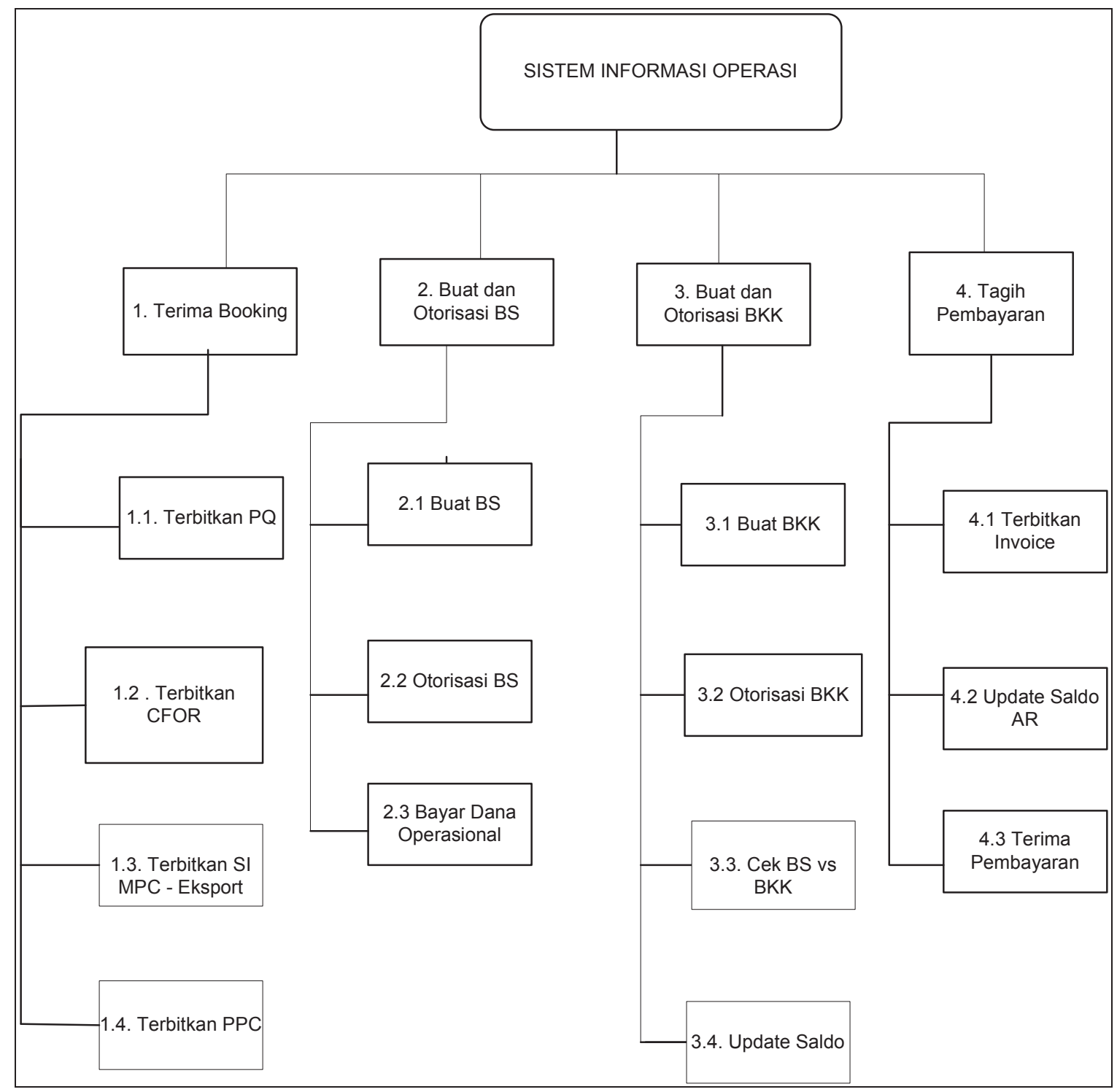

\section{Gambar 7 . Diagram Dekomposisi Fungsional}

\section{Sumber : PT SIG, SOP}

Pada pembahasan ini penulis membagi sistem informasi operasi PT MPC ke dalam 4 (empat) fungsi atau proses, yaitu : Proses Terima Booking, Proses Buat dan Otorisasi Bon Sementara (BS), Proses Buat dan Otorisasi BKK (Bukti Kas Keluar) dan Proses Tagih Pembayaran.
3. Membuat Daftar Event Respons atau Use Case

Membuat daftar kejadian response (event-response) atau use case dalam menggambarkan pemodelan proses logikal dilakukan untuk mennetukan kejadian bisnis apa yang harus dihadapi sistem, dan respon apa yang sesuai untuk tiap-tiap kejadian. Daftar kejadian-respon 
untuk Sistem Informasi perusahan adalah sbb :

Tabel 1.2

Daftar Kejadian -Response (use case)

\begin{tabular}{|c|c|c|c|}
\hline Aktor & Kejadian & Pemicu & Respon \\
\hline Pelanggan & $\begin{array}{l}\text { Mengajukan } \\
\text { permohonan } \\
\text { Price } \\
\text { Quotation }\end{array}$ & $\mathrm{RFQ}$ & $\begin{array}{ll}\text { 1. } & \text { Cetak } \\
& \text { PQ } \\
\text { 2. } & \text { Create } \\
\text { Database } \\
\text { PO }\end{array}$ \\
\hline Pelanggan & $\begin{array}{l}\text { Memberikan } \\
\text { data } \\
\text { persetujuan }\end{array}$ & SI & $\begin{array}{l}\text { 1. Cetak SI } \\
\text { 2. Create } \\
\text { Database } \\
\text { SI }\end{array}$ \\
\hline $\begin{array}{l}\text { Shipping } \\
\text { Line }\end{array}$ & $\begin{array}{l}\text { Memberikan } \\
\text { jadwal kapal }\end{array}$ & SI & $\begin{array}{l}\text { 1. Update } \\
\text { database } \\
\text { SI }\end{array}$ \\
\hline Pelanggan & $\begin{array}{l}\text { Melakukan } \\
\text { transaksi } \\
\text { pembayaran }\end{array}$ & Invoice & $\begin{array}{l}\text { 1. } \text { Cetak } \\
\text { Invoice } \\
\text { 2. Create } \\
\text { Database } \\
\text { invoice }\end{array}$ \\
\hline
\end{tabular}

Sumber : PT SIG , Data diolah
4. Membuat Diagram Dekomposisi Kejadian

Setelah membuat diagram dekomposisi fungsional, langkah selanjutnya dalam membangun pemodelan proses logis adalah membuat Diagram Dekomposisi Kejadian, yaitu dengan menambhkan tiap-tiap kejadian dalam sistem ke dalam Diagram Dekomposisi Fungsional.

Kejadian-kejadian dalam sistem dapat diidentifikasi dengan membuat daftar kejadian-respon atau pendekatan use-case.

Diagram Dekomposisi Kejadian dapat dilihat pada gambar 8 .

5. Membuat Diagram Primitif

Setelah membangun diagram dekomposisi kejadian, langkah selanjutnya dalam membangun pemodelan proses logika adalah membuat diagram primitif, yaitu dengan menambahkan detil dari setiap kejadian dalam sistem.

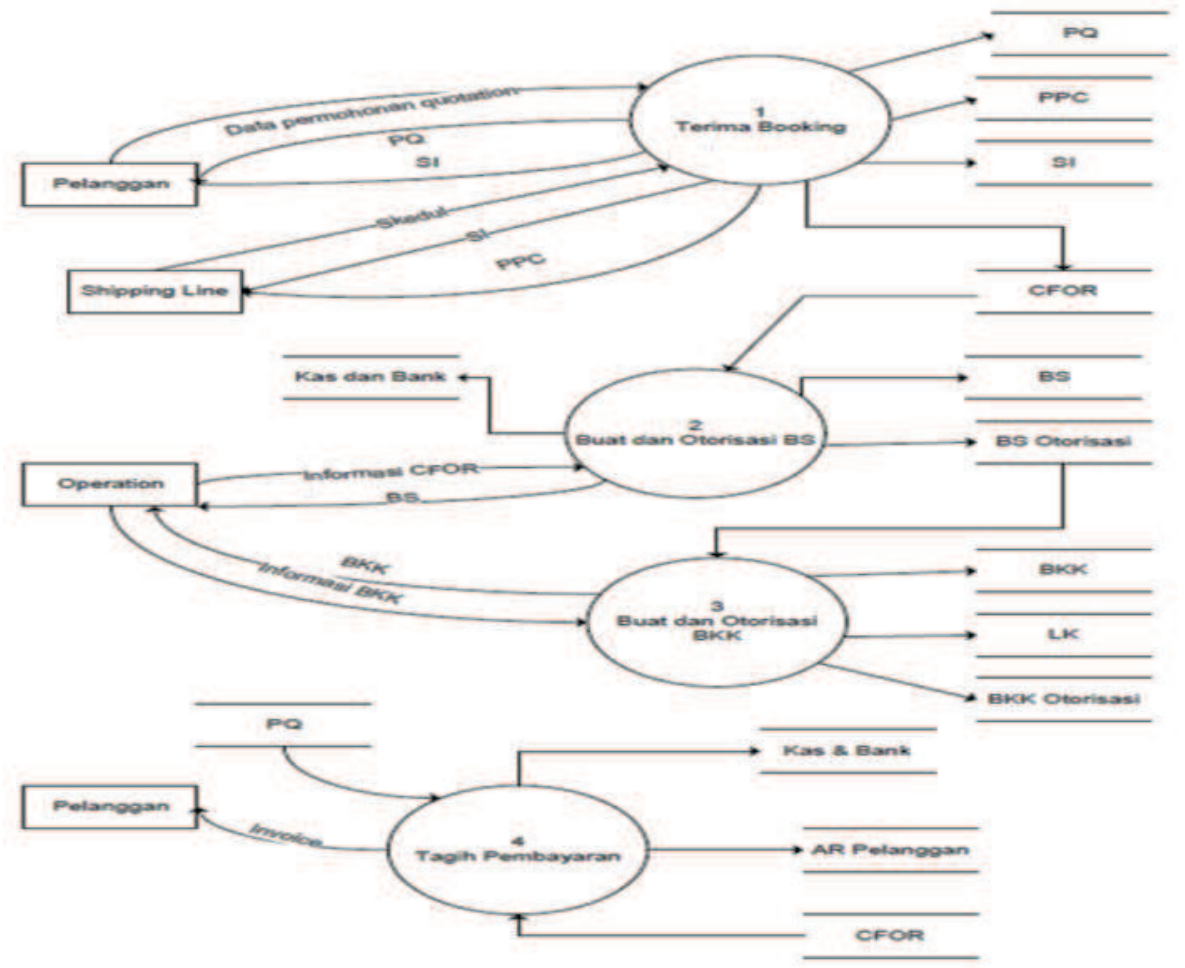

Gambar 8

Diagram dekomposisi kejadian

Sumber : PT SIG 
Diagram aliran data digambarkan secara bertingkat, mulai dari diagram aliran data level o, level 1 dan seterusnya.

ingin mendapatkan daftar harga untuk tujuan pengiriman yang diinginkan.

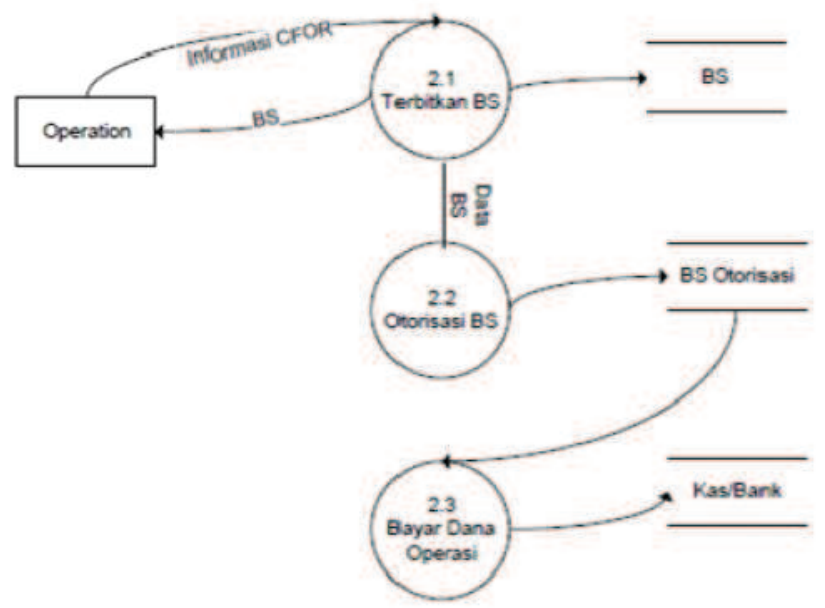

Gambar 9

DFD Level 1 : Proses Terima Booking

\section{Proses 1 - Penerimaan Pesanan} (Booking)

Proses penerimaan booking ini mencakup 4 (empat) hal yakni sub proses Terbitkan PQ (Price Quotation), sub proses Terbitkan CFOR, sub proses Terbitkan SI (Shipping Instruction) dan sub proses Terbitkan PPC.

Diagram aliran data untuk proses penerimaan booking ini dapat dilihat pada gambar berikut ini :

\section{Diagram Dekomposisi \\ Kejadian}

Sub Proses 1.1. Terbitkan PQ (Price Quotation)

Sub Proses Terbitkan PQ terjadi bila pelanggan ingin memakai jasa PT MPC dan sebelumnya
Sebelum diterbitkan PQ, terlebih dahulu pelanggan harus memberikan permintaan quotation yang disebut RFQ (Request for Quotation). PQ ini kemudian dicetak dan kemudian dikirim/difaxkan ke pelanggan untuk dipertimbangkan oleh pelanggan apakah quotation tersebut cocok untuk mereka. Jika PQ disepakati maka pekerjaan tersebut akan ditangani perusahaan. Data PQ yang telah diinput akan disimpan dalam data store PQ dan kemudian dicetak untuk dikirim ke pelanggan. Sementara data permohonan quotation (RFQ) menjadi input untuk sub proses ini. Sedangkan output sub proses ini berupa PQ yang diserahkan kepada Pelanggan dan update data store PQ.Sub Proses 1.2 Terbitkan CFOR 
Sub proses terbitkan CFOR terjadi apabila order disetujui untuk diserahkan kepada MPC. Dengan CFOR ini dapat diinput biaya-biaya yang diestimasi akan terjadi dalam aktivitas operasi dan juga laba atas pekerjaan tersebut. Jika pekerjaan sudah selesai dan barang sudah dikirim, maka CFOR ini dilengkapia dengan biaya aktual yang terjadi dan disimpan dalam database. CFOR akan dicetak untuk diserahkan kepada bagian keuangan sebagai dokumen pendukung dalam membuat invoice kepada pelanggan. Data persetujuan yang berupa SI dari pelanggan (aktivitas import) dan data dari data store PQ menjadi input untuk sub proses ini. Sedangkan output dari sub proses ini adalah update data store CFOR.

\section{Sub Proses 1.3 Terbitkan SI}

Sub Proses terbitkan SI terjadi pada kegiatan ekspor. Shipping Instruction yang diajukan disini merupakan dokumen yang dikeluarkan oleh MPC yang ditujukan kepada shipping line sebagai dasar untuk pembuatan Master B/L atau Direct B/L. Data dari data store CFOR dan jadwal kapal dari Shipping Line merupakan input dari sub proses ini. Sedangkan output sub proses ini adalah Shipping Instruction yang dibuat oleh MPC dan ditujukan kepada Shipping Line dan juga update data store SI.

\section{Sub Proses 1.4 Terbitkan PPC}

Penerbitan PPC yang ditujukan kepada pelayaran ini adalah untuk meminjam container yang selama ini dipakai oleh pelayaran. Ketika container telah tiba di pelabuhan tujuan dan MPC bertugas untuk meneruskan barang tersebut ke depo, maka disinilah terjadi peminjaman container dengan terlebih dahulu mengirimkan Surat Permohonan Pinjam Container kepada pelayaran tersebut. Input dari sub proses ini adalah dari data store SI dan outputnya berupa surat PPC (Permohonan Pinjam Container) yang ditujukan kepada Shipping Line.

\section{Proses 2 - Penerbitan dan Otorisasi BS}

Proses pengajuan budget dana operasi terdiri dari tiga sub proses, yakni sub proses terbitkan BS, sub proses otorisasi BS dan sub proses Bayar Dana Operasi. Untuk melakukan kegiatan operasional tentu dibutuhkan biaya. Untuk itu bagian operasi mengajukan budget dana operasi ke bagian keuangan dengan mengisi Bon Sementara (BS). Data pengajuan BS diinput untuk kemudian dicetak dan disimpan dalam database BS. BS yang telah dicetak harus diotorisasi oleh manajer yang bersangkutan. Setelah proses otorisasi selesai, maka transaksi pembayaran dana operasi kepada bagian operation dapat dilakukan.

\section{Sub Proses 2.1 Terbitkan BS}

Input untuk sub proses ini adalah data dari CFOR dan outputnya digunakan untuk mengupdate data store BS. 


\section{Sub Proses 2.2 Otorisasi BS}

Input sub proses ini adalah data dari sub proses 2.1 Terbitkan BS dan outputnya digunakan untuk mengupdate BS otorisasi.

\section{Sub Proses 2.3 Bayar Dana Operasi}

Input sub proses ini adalah data dari data store BS Otorisasi BS dan data store Kas dan Bank sedangkan outputnya adalah untuk mengupdate data store Kas dan Bank. dipakai untuk semua aktivitas operasionalnya. Bila semua data telah lengkap dan diinput maka dikeluarkanlah BKK dan disimpan dalam database.BKK yang telah dikeluarkan harus diotorisasisi oleh manajer operasional.

Kemudian BKK yang telah diotorisasi dibandingkan dengan BS yang sebelumnya telah diinput dan dicetak. Pengecekan ini untuk mendapatkan informasi apakah uang yang sebelumnya telah diberikan masih terdapat kelebihan atau apakah terdapat kekurangan.

Gambar 10

DFD Level 1: Proses Terbitkan dan

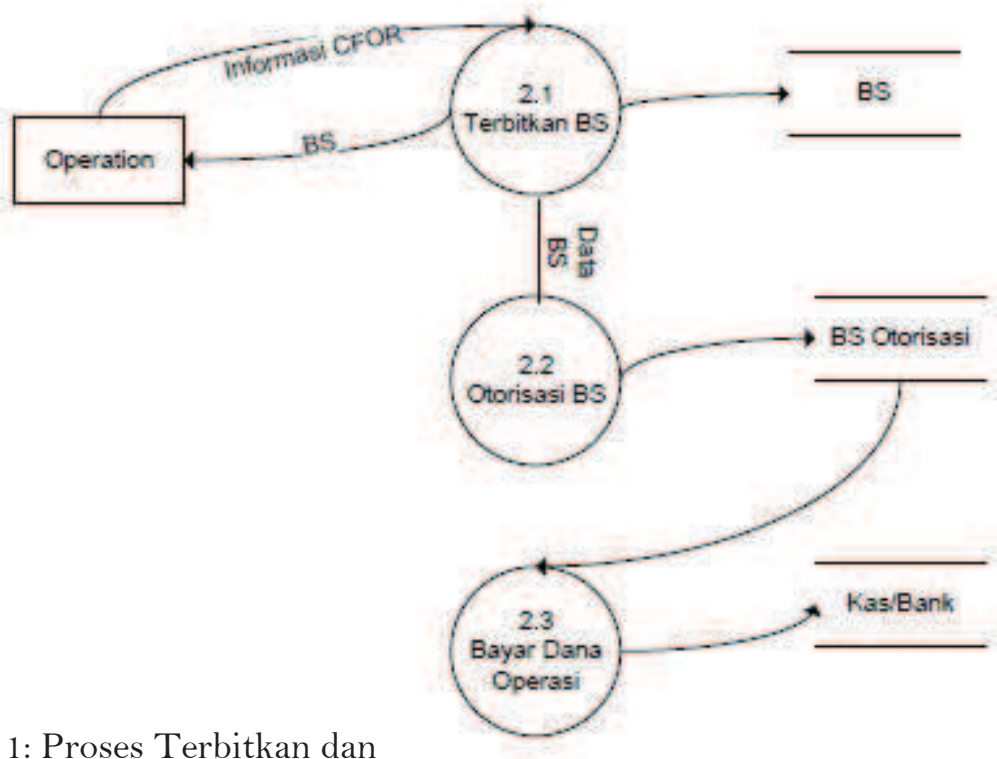

Otorisasi BS

\section{Proses 3 - Penerbitan dan Otorisasi BKK}

Proses pertanggungan biaya operasi ini terdiri dari 4 sub proses yakni : sub proses terbitkan BKK (Bukti Kas Keluar), sub proses otorisasi BKK, sub proses cek antara BS dan BKK, serta sub proses up date saldo.

Sub proses terbitkan BKK terjadi apabila bagian operation datang dengan membawa semua datadata yang berhubungan dengan pertanggungjawaban uang yang
Selanjutnya informasi dicetak melalui LK. Kemudian setelah adanya laporan LK, informasi tentang saldo AR harus diupdate. Dan kelebihan uang/kekurangan uang diinformasikan kepada bagian keuangan untuk disetor kembali (bila terjadi kelebihan) dan dimintakan (bila terjadi kekurangan).

Diagram aliran data proses terbitkan dan otorisasi BKK dapat dilihat pada gambar berikut ini. 
(gambar 4.11) hal.78Sub Proses 3.1 - Terbitkan BKK

Input dari sub proses ini adalah dari data store BS Otorisasi dan outputnya adalah digunakan untuk mengupdate data store BKK dan sebagai input untuk sub proses 3.2 - Otorisasi BKK.

Sub Proses 3.2 - Otorisasi BKK

Input dari sub proses ini adalah sub proses 3.1 - Terbitkan BKK sedangkan outputnya adalah untuk mengupdate data store BKK Otorisasi.
Input dari sub proses ini adalah dari data store LK dan dari data store Kas/Bank, sedangkan outputnya adalah untuk mengupdate data store Kas/Bank.

\section{Proses 4 - Tagih Pembayaran}

Proses penagihan atas jasa terdiri dari tiga hal, yakni sub proses terbitkan invoice, sub proses up date saldo AR dan sub proses transaksi penerimaan pembayaran. Semua data yang berkenaan dengan biaya yang harus ditanggung pelanggan (termasuk laba perusahaan) diinput dan kemudian dicetak dan disimpan dalam database. Dengan terbitnya invoice ini akan mengupdate saldo AR pelanggan.

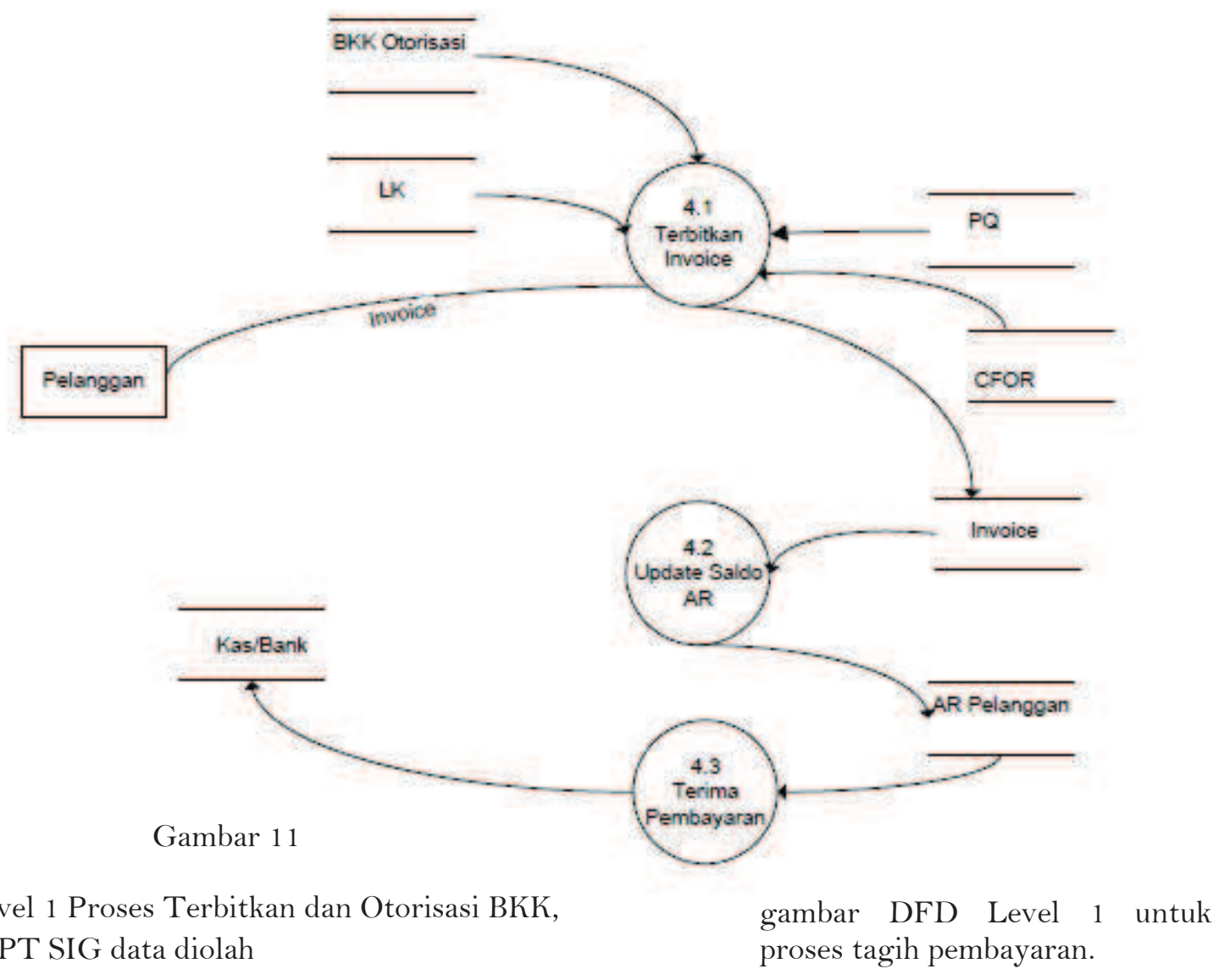

DFD Level 1 Proses Terbitkan dan Otorisasi BKK, sumber: PT SIG data diolah

\section{Sub Proses 3.3 - Cek BS vs BKK}

Input dari sub proses ini adalah dari data store BKK Otorisasi dan dari data store BS Otorisasi. Sedangkan outputnya adalah Laporan Keuangan (LK)

Sub Proses 3.4 - Update Saldo

\section{Sub Proses 4.1}

Data dari data store BKK Otorisasi, LK, PQ, CFOR akan menjadi input bagi sub proses ini. Sedangkan outputnya adalah invoice kepada pelanggan dan juga update data store invoice.

Sub Proses 4.2 
Data dari data store invoice dan dari data store AR Pelanggan akan menjadi input bagi sub proses ini. Sedangkan outputnya adalah untuk mengupdate data store AR pelanggan.

\section{Sub Proses 4.3}

Data dari data store AR Pelanggan dan pembayaran dari pelanggan akan menjadi input bagi sub proses ini. Sedangkan outputnya untuk mengupdate data store Kas/Bank.

\section{PENUTUP}

\section{Simpulan}

Pemodelan proses mencakup proses aliran data yang dimodelkan dengan Diagram Arus Data (DAD) dimana dengan pemodelan ini dapat diidentifikasikan sumber data dan entitas yang terlibat dalam menghasilkan atau menggunakan data baru atau yang disimpan. Dengan adanya sistem informasi ini diharapkan fungsi utama perusahaan sebagai fungsi freight forwarding dapat berjalan dengan baik. Fungsi pembuatan dokumen dapat dilakukan dengan komputerisasi sehingga menghilangkan kesalahan-kesalahan manual yang sering terjadi. Diharapkan administrasi data lebih teratur, pencarian data lebih mudah dan lebih cepat, laporan atau informasi yang diperlukan dapat disajikan secara tepat waktu. Selain itu diharapkan data dapat diambil oleh pihak yang membutuhkan dengan mudah tanpa harus melalui birokrasi yang panjang sehingga dapat menghemat waktu. Serta dokumen-dokumen yang dibutuhkan oleh pelanggan dapat dengan mudah dan cepat disediakan dengan tingkat keakuratan yang tinggi. Sehingga diharapkan tidak terjadi penolakan dokumen oleh pihak pelayaran terkait karena kesalahan penulisan dokumen.

\section{Saran}

Fokus pembahasan dalam penelitian ini adalah analisis logikal sistem informasi dimana masih diperlukan tahap selanjutnya untuk perancangan sistem informasi. Pembangunan dan implementasi sistem diperlukan keterlibatan user dan programmer. Keterlibatan user diperlukan untuk menentukan kepuasan user terhadap sistem informasi yang akan dibangun dan keterlibatan tekhnologi diperlukan untuk memberikan pertimbangan tekhnis atau tekhnologi yang digunakan untuk membangun sistem informasi.

Penelitian ini masih dalam tahap awal yaitu analisis logis atas sistem yang ada, maka penelitian ini masih dapat dikembangkan lebih lanjut, seperti melakukan perancangan fisik.

\section{DAFTAR PUSTAKA}

Jogiyanto, HM. Analisi dan Desain Sistem Informasi : Pendekatan Terstruktur Teori dan Praktek Aplikasi Bisnis. Edisi kedua. Yogyakarta. Andi, 2001

Romney, Marshall B and Steinbart, Paul John. Accounting Information System. 8th edition. New Jersey : Prentice Hall, 2000

Whitten, Jeffrey L., Bentley, Lonie D., Dittman, Kevin C. System Analysis and Design Methods.

New York : McGraw Hill, 2000 